\title{
An assessment of water quality in dam reservoirs, considering their aggressive properties
}

\author{
Piotr Koszelnik ${ }^{1, *}$, Jadwiga Kaleta $^{1}$, and Lilianna Bartoszek $^{1}$ \\ ${ }^{1}$ Faculty of Civil and Environmental Engineering and Architecture, Rzeszów University of \\ Technology, al. Powstańców Warszawy 6, 35-959 Rzeszów, Poland
}

\begin{abstract}
The paper presents the water classification of four small retention reservoirs on the basis of selected physical and chemical indicators, such as: conductivity, $\mathrm{pH}$ level, dissolved oxygen, calcium hardness, general hardness and alkalinity. Three reservoirs (Ożanna, Kamionka and Cierpisz) are within the limits in terms of average values for the second class of water quality. Water in the Nowa Wieś reservoir does not qualify as second quality class of surface water. These reservoirs have had very irregular seasonal variations of water quality. Unambiguous correlations have not been established. Aggressive properties of water have been tested on the basis of Langelier (IL) or Ryznar (IR) indexes and calcium carbonate saturation [pHs]. Waters in the Ożanna and Nowa Wieś reservoirs do not have aggressive properties. Both the Kamionka and Cierpisz reservoirs are characterized by corrosive and leaching aggressiveness.
\end{abstract}

\section{Introduction}

Large retention reservoirs are designed to protect us from extreme phenomena such as periodic floods and droughts [1]. However, their retention capacity is really low. So-called small retention plays an important role in collecting water in small reservoirs by stopping or slowing down the runoff. In lowlands, small retention is mainly focused on increasing retention possibilities and preventing droughts and floods. In mountainous areas, small retention is aimed at counteracting the effects of storm water runoff. Retention reservoirs are most often multipurpose facilities. Their most important functions include water collection for municipal and agricultural purposes or flood protection. They are also used for recreational purposes, hydropower and fishing [2, 3]. The main problem occurring in ecosystems exposed to an uncontrolled accumulation of nutrients from the catchment area is the eutrophication process $[4,5]$.

Dam reservoirs, which are an integral part of civilization development, have many features that distinguish them from natural lakes or rivers, hence they constitute a different category of surface water reservoirs [6]. That is why the interpretation of anthropogenically

\footnotetext{
* Corresponding author: pkoszel@prz.edu.pl
} 
accelerated processes of their water degradation is so important [7]. When using dam reservoirs as water supply systems, it is important to determine water aggressiveness first. In treatment processes, especially during coagulation, the aggressiveness is increased, related to the introduction of reagents that disturb the carbonate-calcium balance or increase the content of interacting ions [8].

The most important factors that affect the corrosive aggressiveness of water are: $\mathrm{pH}(\mathrm{pH}$ above 7); temperature (an increase in temperature increases the corrosivity of water); the alkalinity of water - when it is less than $1.36 \mathrm{mval} / \mathrm{L}$, water is corrosive regardless of other corrosivity indexes; hardness (recommended value: 60 - $500 \mathrm{mgCaCO}_{3} / \mathrm{L}$ ); dissolved oxygen; aggressive $\mathrm{CO}_{2}$; gases $\left(\mathrm{NH}_{3}, \mathrm{H}_{2} \mathrm{~S}, \mathrm{CH}_{4}\right)$; salinity, especially $\mathrm{Cl}^{-}$and $\mathrm{SO}_{4}{ }^{2-}$ anions; water flow turbulence; contamination with microorganisms (microbiological corrosion) or corrosion inhibitors. Corrosive aggressiveness is determined based on the $\mathrm{pH}$ of calcium carbonate saturation, pHs, and Langelier (IL) and Ryznar (IR) indexes. Aggressiveness is caused by very soft water. In this case, mainly the low content of calcium ions decides. Corrosion occurs due to the dissolution and leaching of calcium carbonate. The greatest sensitivity to this type of destruction is specifically exhibited in the first period after application. Corrosion is particularly dangerous when water is in motion (water structure destruction) $[9,10]$.

The purpose of the work was to classify the water quality of four small retention reservoirs as well as to assess their corrosive aggressiveness and leaching aggressiveness.

\section{Materials and methods}

The research was conducted on four small dam reservoirs in Southeastern Poland. Their characteristics are included in Table 1. Surface water samples were collected in 2013-2014, (from spring to autumn) from 2 or 3 sites located in the backwater, near the dam and possibly in the centre of the reservoir. The samples were taken for temperature, conductivity, $\mathrm{pH}$ and dissolved oxygen concentration measurement (in situ testing), using the multi-parameter Hach Lange HQ40D meter. Calcium concentration, hardness and alkalinity were determined using standard laboratory techniques in accordance with Polish Standards.

Table 1. Parameters of analysed reservoirs [11-13].

\begin{tabular}{|c|c|c|c|c|c|}
\hline Reservoir & $\begin{array}{c}\text { Capacity } \\
{\left[\mathbf{1 0}^{\mathbf{3}} \mathbf{~ m}^{\mathbf{3}}\right]}\end{array}$ & $\begin{array}{c}\text { Depth } \\
\text { avg.(max.) } \\
{[\mathbf{m}]}\end{array}$ & $\begin{array}{c}\text { Reservoir } \\
\text { area } \\
{[\mathbf{h a}]}\end{array}$ & $\begin{array}{c}\text { Retention } \\
\text { time } \\
{[\mathbf{d a y}]}\end{array}$ & $\begin{array}{c}\text { Catchment } \\
\text { area } \\
{\left[\mathbf{k m}^{\mathbf{2}}\right]}\end{array}$ \\
\hline Ożanna & 275 & $1,4(3,7)$ & 20 & 3,5 & 136,3 \\
\hline Kamionka & 105 & $1,5(3,0)$ & 7 & 4,8 & 84,8 \\
\hline Cierpisz & 22 & $0,9(1,5)$ & 2,3 & 1,2 & 54,5 \\
\hline Nowa Wieś & 75 & $1,0(3,0)$ & 3,0 & 1,3 & 208,1 \\
\hline
\end{tabular}

The water stability criterion was determined by calculating the $\mathrm{pH}$ in steady state (saturation) with solid calcium carbonate according to the dependence [13]:

$$
p H s=(9,3+A+B)-(C+D)
$$

where:

$\mathrm{pHs}-\mathrm{pH}$ of saturated water,

and individual indicators are functions:

$A$ - total dissolved salts (in correlation with the conductivity),

$B$ - water temperature,

$C$ - calcium hardness, 
$D$ - basic alkalinity.

The stability of the studied waters was assessed on the basis of the Langelier (IL) and the Ryznar (IR) indexes [14]:

$$
\begin{aligned}
& I L=p H-p H s \\
& I R=2 p H s-p H
\end{aligned}
$$

where:

$\mathrm{pH}-\mathrm{pH}$ value,

$p H s-\mathrm{pH}$ value in calcium carbonate saturation state.

\section{Results and discussion}

A detailed analysis of the obtained results of selected physico-chemical parameters in 20132014 showed that the quality of water taken from various points in these reservoirs (backwater, centre, dam) may turn out to be slightly different in the end. As an example, the reservoir in Kamionka was considered, in which the differences were the largest (the longest retention time of $4.8 \mathrm{~d}$ ) in terms of conductivity, $\mathrm{pH}$, dissolved oxygen, hardness and alkalinity (Figure 1). In further analyses of the water quality, sampling points were not taken into account, and the results were referred to the entire reservoir (Table 2). Figure 2A-D show examples of seasonal changes made to the parameters at the sampling point.

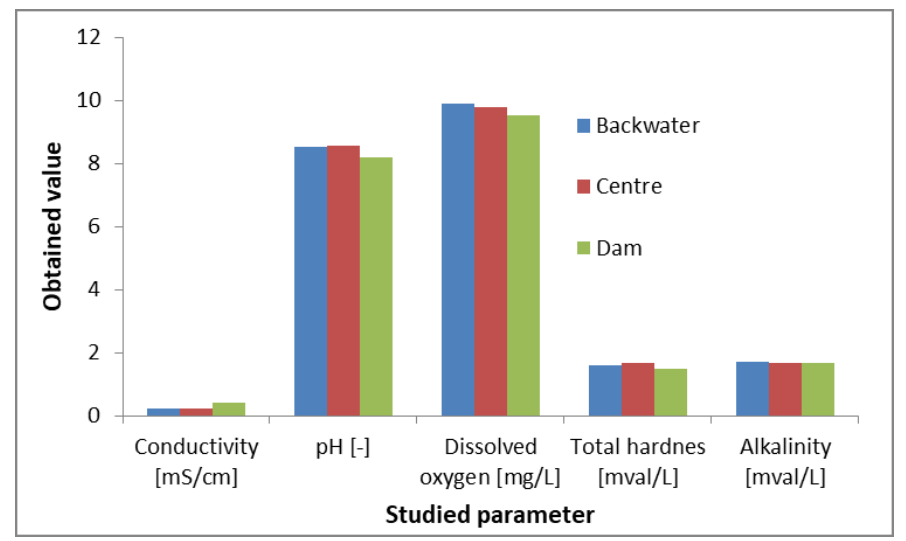

Fig. 1. Water quality of Kamionka reservoir (sampling - October 2014).

The water temperature of the studied reservoirs in the period of spring, summer and autumn over two years changed within the limits of $12.5-28.5{ }^{\circ} \mathrm{C}$. The average temperature value fluctuated around $20^{\circ} \mathrm{C}$.

The salinity of water expressed by measuring the conductivity in the Ożanna, Kamionka and Cierpisz reservoirs ranged from $247-288 \mu \mathrm{S} / \mathrm{cm}$, while the maximum values were practically twice as high as the first value $(429-502 \mu \mathrm{S} / \mathrm{cm})$. Water conductivity in the Nowa Wieś reservoir was the largest and had the average value of $467 \mu \mathrm{S} / \mathrm{cm}$. Seasonal conductivity changes in the studied periods were very irregular. In 2013, conductivity values in the Ożanna reservoir showed an upward trend from spring to autumn, but in 2014 higher values were reported in the spring and autumn, and the lowest in the summer. In the waters of the Kamionka and Cierpisz reservoirs and in 2013, the highest values of conductivity were marked in the summer, while in 2014 the maximum value of this 
parameter decreased in autumn. The conductivity in the Nowa Wieś reservoir reached its highest values in spring and autumn.
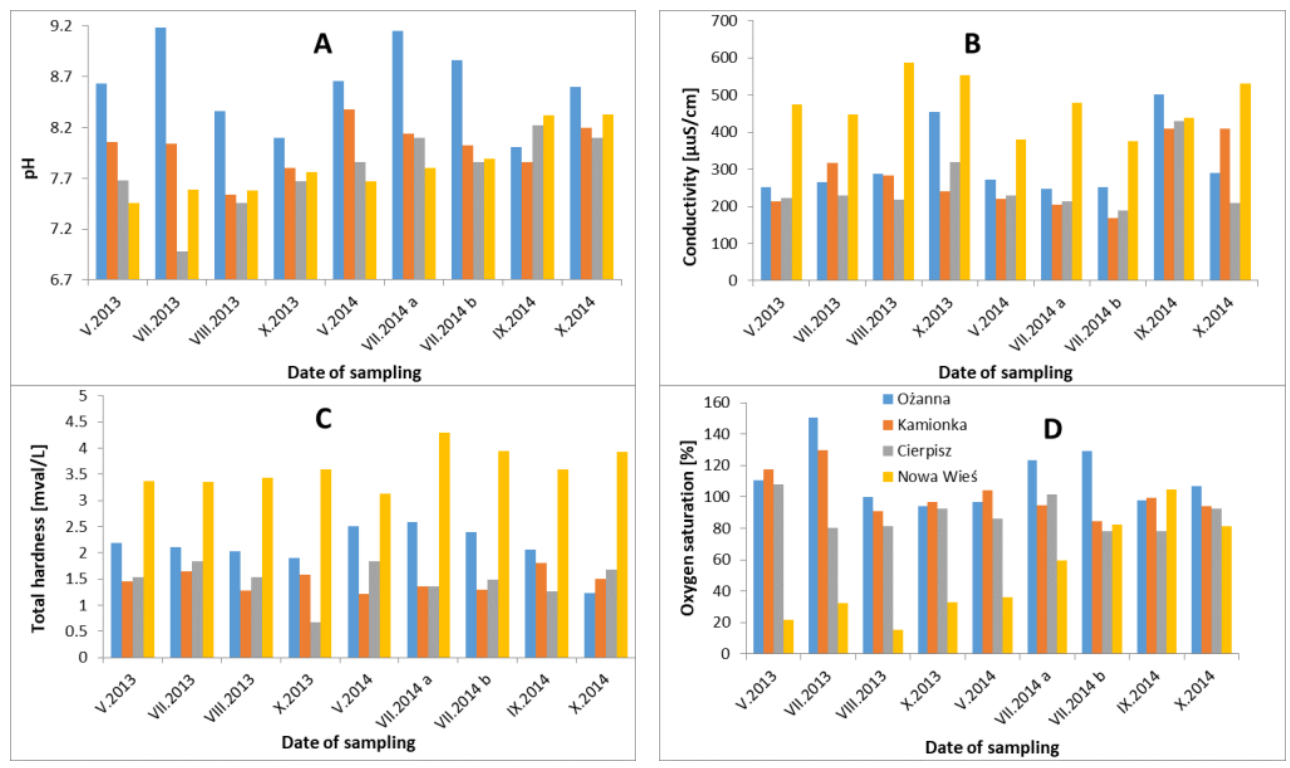

Fig. 2. Seasonal variations of $\mathrm{pH}(\mathrm{A})$, conductivity (B), total hardness (C) and oxygen saturation of the studied reservoirs ( $a$ - beginning of June, $b$ - end of June).

Table 2. Representative values of selected water indicators of analysed reservoirs.

\begin{tabular}{|c|c|c|c|c|c|c|c|}
\hline Value & $\begin{array}{c}\text { Temp. } \\
{\left[{ }^{\circ} \mathrm{C}\right]}\end{array}$ & $\begin{array}{c}\text { Conductivity } \\
{[\mu \mathrm{S} / \mathrm{cm}]}\end{array}$ & pH & $\begin{array}{c}\text { Dissolved } \\
\text { oxygen } \\
{\left[\mathrm{mgO}_{2} / \mathrm{L}\right]}\end{array}$ & $\begin{array}{l}\text { Calcium } \\
{[\text { mval/L] }}\end{array}$ & $\begin{array}{c}\text { Total } \\
\text { hardness } \\
\text { [mval/L] }\end{array}$ & $\begin{array}{c}\text { Total } \\
\text { alkalinity } \\
{[\mathrm{mval} / \mathrm{L}]}\end{array}$ \\
\hline & \multicolumn{7}{|c|}{ Ożanna $(n=27)$} \\
\hline Minimum & 13.0 & 245 & 7.50 & 5.97 & 1.05 & 1.23 & 1.11 \\
\hline Maximum & 28.5 & 502 & 9.53 & 12.04 & 2.46 & 2.69 & 2.65 \\
\hline Average & 20.2 & 288 & - & 9.58 & 1.87 & 2.18 & 2.20 \\
\hline \multirow[t]{2}{*}{ SD } & 5.1 & 58 & 0.5 & 1.3 & 0.35 & 0.40 & 0.47 \\
\hline & \multicolumn{7}{|c|}{ Cierpisz $(\mathrm{n}=18)$} \\
\hline Minimum & 14.3 & 181 & 6.98 & 5.78 & 0.52 & 0.54 & 1.48 \\
\hline Maximum & 25.6 & 429 & 8.53 & 9.81 & 1.76 & 1.86 & 2.24 \\
\hline Average & 19.8 & 247 & - & 8.18 & 1.30 & 1.45 & 1.75 \\
\hline \multirow[t]{2}{*}{$\mathrm{SD}$} & 4.3 & 69 & 0.4 & 1.3 & 0.35 & 0.37 & 0.23 \\
\hline & \multicolumn{7}{|c|}{ Kamionka $(\mathrm{n}=27)$} \\
\hline Minimum & 14.1 & 168 & 7.2 & 5.96 & 0.79 & 0.82 & 1.25 \\
\hline Maximum & 25.5 & 473 & 8.56 & 11.53 & 1.68 & 1.89 & 2.05 \\
\hline Average & 20.0 & 247 & - & 9.11 & 1.35 & 1.49 & 1.68 \\
\hline \multirow[t]{2}{*}{ SD } & 3.7 & 77 & 0.3 & 1.5 & 0.23 & 0.23 & 0.19 \\
\hline & \multicolumn{7}{|c|}{ Nowa Wieś $(\mathrm{n}=18)$} \\
\hline Minimum & 12.5 & 281 & 7.46 & 1.50 & 2.54 & 3.13 & 2.78 \\
\hline Maximum & 28.2 & 586 & 8.46 & 8.73 & 3.68 & 4.30 & 5.14 \\
\hline Average & 18.4 & 467 & - & 4.74 & 3.08 & 3.64 & 3.92 \\
\hline SD & 5.7 & 78 & 0.31 & 2.3 & 0.34 & 0.41 & 0.67 \\
\hline
\end{tabular}

The waters of the Ożanna reservoir were characterized by the highest $\mathrm{pH}$ values, with its maximum value reaching $\mathrm{pH}=9.53$. The $\mathrm{pH}$ of other analysed reservoirs ranged from 7.84 to 7.98 . In the Ożanna reservoir the highest $\mathrm{pH}$ values occurred in the summer. 
Kamionka reservoir was characterized by the highest values of the $\mathrm{pH}$ in May, and the Cierpisz and Nowa Wieś reservoirs in autumn.

The Ożanna, Cierpisz and Kamionka reservoirs water were characterized by good

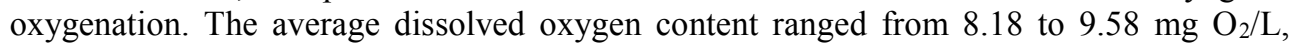
while the average oxygen saturation was $88-103 \%$. The Nowa Wieś reservoir was different in this respect; the average oxygen content was $4.74 \mathrm{mgO}_{2} / \mathrm{L}$, and there was only $50 \%$ saturation. Oxygen saturation in the Ożanna and Kamionka reservoirs reached the highest values in summer. In the Cierpisz reservoir no significant seasonal relation between these properties was found. The water of Nowa Wieś reservoir showed the highest degree of oxygenation in autumn.

The highest levels of calcium concentration (2.54 - $3.68 \mathrm{mval} / \mathrm{L})$, total hardness (3.13 $4.30 \mathrm{mval} / \mathrm{L})$ and alkalinity $(2.78-5.14 \mathrm{mval} / \mathrm{L})$ were reported in the waters of the Nowa Wieś reservoir. Next in this respect, you can set the water of the Ożanna reservoir; calcium, hardness and alkalinity respectively within the limits of $1.05-2.46 \mathrm{mval} / \mathrm{L}, 1.23-2.69$ $\mathrm{mval} / \mathrm{L}$ and $1.1-2.65 \mathrm{mval} / \mathrm{L}$. The Cierpisz and Kamionka reservoirs had low calcium $(0.52-1.68 \mathrm{mval} / \mathrm{L})$, hardness $(0.54-1.89 \mathrm{mval} / \mathrm{L})$ and alkalinity $(1.25-2.05 \mathrm{mval} / \mathrm{L})$ levels. In the tested reservoirs, general alkalinity (acidic carbonates $\mathrm{HCO}_{3}{ }^{-}$) was often higher than the total hardness value. This shows the presence of the so-called alkalinity caused by sodium $\left(\mathrm{NaHCO}_{3}\right)$ and/or potassium $\left(\mathrm{KHCO}_{3}\right)$ bicarbonate. Water hardness in the Ożanna reservoir showed a downward trend from spring to autumn. In other reservoirs, this parameter changed very irregularly. Changes in the calcium and alkalinity content were in close correlation with changes in the hardness of the analysed waters.

For each water measurement, the $\mathrm{pH}$ of calcium carbonate saturation (pHs) was calculated. Next, the Langelier index (IL) and the Ryznar stability index (IR) were determined (Table 3). According to [15], in the case of calcium carbonate saturation, the concentration of calcium ions and alkalinity are the factors that have an actual impact on the $\mathrm{pH}$ value. As to the mineralization degree, it is considered less important.

The interpretation of water stability by the Langelier index value is as follows:

- $\quad \mathrm{IL}<0$ - water is unsaturated in relation to $\mathrm{CaCO}_{3}$ and has aggressive properties,

- $\quad \mathrm{IL}=0$ - water is stable, i.e. it is not aggressive, but also does not tend to produce protective $\mathrm{CaCO}_{3}$ layers,

- $\quad$ IL $>0$ - water tends to produce $\mathrm{CaCO}_{3}$ deposits, so it is non-aggressive.

Table 3. Corrosion indicators of water of analysed reservoirs.

\begin{tabular}{|c|c|c|}
\hline Reservoir & Langelier index $\left(\mathrm{I}_{\mathrm{L}}\right)$ & Ryznar index $\left(I_{R}\right)$ \\
\hline Ożanna & from $(+) 0.2$ to $(+) 1.43$ & $6.62-7.02$ \\
\hline Kamionka & $\begin{array}{c}\text { from }(-) 0.80 \text { to }(-) 0.02 \\
\text { during IX and X of } 2014 \text { from }(+) 0.2 \text { to } \\
(+) 0.41\end{array}$ & $7.50-9.29$ \\
\hline Cierpisz & $\begin{array}{c}\text { from }(-) 0.24 \text { to }(-) 0.93 \\
\text { during IX and X of } 2014 \text { from } 0.00 \text { to }(+) 0.33\end{array}$ & $7.47-9.53$ \\
\hline Nowa Wieś & $\begin{array}{c}\text { from }(+) 0.06 \text { to }(+) 0.96 \\
\text { during V of } 2013 \text { from }(-) 0.25 \text { to }(-) 0.34\end{array}$ & $6.54-8.14$ \\
\hline
\end{tabular}

The water classification, depending on the value of the Ryznar index, is presented in Table 4. According to the Langelier index, the Ożanna has non-aggressive waters. However, according to the Ryznar index, waters may have some aggressiveness. Due to the low hardness and alkalinity there can be leaching aggressiveness. Waters in the Kamionka and Cierpisz reservoirs can be considered aggressive due to the values of both the Langelier and Ryznar indexes. Similarly in the Ożanna reservoir, due to its very low hardness, leaching aggressiveness may also occur. A high concentration of dissolved oxygen is just another factor that influences water aggressiveness in the Ożanna, Kamionka and Cierpisz 
reservoirs. The water from the Nowa Wieś reservoir is non-aggressive water, except for results obtained from samples taken in May 2013, which clearly indicate its aggressive nature. This one-off case was related to the lowest $\mathrm{pH}$ value in this reservoir.

Table 4. Water classification according to the Ryznar index.

\begin{tabular}{|c|c|}
\hline Value of the Ryznar index (IR) & Water properties \\
\hline Below 5.0 & Strong tendency of $\mathrm{CaCO}_{3}$ precipitation \\
\hline $5.0-6.0$ & Small tendency of $\mathrm{CaCO}_{3}$ precipitation \\
\hline $6.0-7.0$ & Precipitation of $\mathrm{CaCO}_{3}$ is not occur \\
\hline $7.0-7.5$ & Aggressiveness of water \\
\hline Above 7.5 & Major aggressiveness of water \\
\hline
\end{tabular}

\section{Conclusions}

- The Nowa Wieś reservoir has the worst values of the analysed parameters. Water quality in this reservoir is probably affected by the largest catchment area of all analysed reservoirs. Seasonal changes in water quality in the range of the analysed parameters are very irregular and no unambiguous dependencies can be determined.

- In the Ożanna and Nowa Wieś reservoirs, the waters are non-aggressive. Water from the Ożanna reservoir may have leaching aggressiveness due to its low hardness.

- The Kamionka and Cierpisz reservoirs contain water of corrosive and leaching aggressiveness.

- Due to the complexity of the corrosion process, none of the indices provide adequate and reliable information. These are the main indicators that allow comparing the corrosivity of different waters and estimating their aggressive nature.

- When using the waters of the analysed reservoirs for water supply purposes, the coagulation process should be analysed in detail to reduce the reaction and aggressive carbon dioxide.

The research was funded by the Polish National Science Centre in the framework of research project No. 2011/03/B/ST10/04998.

\section{References}

1. M. Gutry-Korycka, A. Sadurski, J. Pociask-Karteczka, L. Skrzypczyk L. Nauka, 1, 7798 (2014)

2. M. Wojtkowska, D. Dmochowski, Env. Prot. Eng. 35(2), 57-66 (2009)

3. P. Koszelnik, J. Krupa, S. Rymar, K. Szpara K, Woda, Żywność, Turystyka regionalne uwarunkowania zrównoważonego rozwoju obszarów południowowschodniej Polski, (Związek Gmin Turystycznych Pogórza Dynowskiego, Dynów, 2016)

4. L. Bartoszek, D. Czech D, JCEEA, 61/4, 35-53. (2014). doi:10.7862/rb.2014.125

5. E. Neverova-Dziopak, Z. Kowalewski, Ecol. Chem. Eng. S, 21, 637-650 (2014)

6. M. Wiatkowski, Cz. Rosik-Dulewska, Rocznik Ochrona Środowiska, 18, 468-479 (2016)

7. K. Boryczko, B. Tchórzewska-Cieślak, Env. Prot. Eng. 40(4), 77-92 (2014)

8. A. Rak, Gaz, Woda i Technika Sanitarna, 4, 21-28 (2008)

9. M. Jaśniok, T. Jaśniok, Procedia Engineering, 193, 486-493 (2017) 
10. D. Papciak, J. Kaleta, A. Puszkarewicz. Rocznik Ochrona Środowiska, 13, 1352-1366 (2013)

11. B. Michalec, M. Tarnawski, T. Koniarz, JCEEA, 60 (3/13), 129-142 (2013) doi:10.7862/rb.2013.43

12. L. Bartoszek, R. Gruca - Rokosz, P. Koszelnik, Technologia Wody, 51, 54-58 (2017)

13. R. Gruca - Rokosz, P. Koszelnik, J.A, Tomaszek, Inżynieria Ekologiczna, 26, 196-205 (2011)

14. M. Granops, J. Kaleta, Woda uzdatnianie i odnowa (SGGW, Warszawa, 2005)

15. R. Buchta, W. Dąbrowski, Ochrona Środowiska, 3(70), 21-26 (1998) 